\title{
EARLY EXPERIMENTAL RESULTS OF NERVE GAP BRIDGING WITH SILICON MICROWIRES
}

\author{
V.V. Likhodiievskyi* \\ Bogomolets National Medical University, Kyiv, Ukraine \\ *Corresponding author: Legebrill@gmail.com \\ Received 27 August 2019; Accepted 23 September 2019
}

\begin{abstract}
Background. The incidence of severe peripheral nerves and plexus injuries tends to grow. Autoneurografting is considered as a golden standard method of nerve gap bridging, but existing shortcomings such as additional surgery measures, denervation of other segments of the body, discordance of the neurovascular structure of the damaged nerve and autograft stipulate the development of new material and treatment methods.

Objective. The current study is aimed at estimation of the impact of silicon wires on early morphological changes of the parts of the damaged peripheral nerve after nerve injury and grafting with the use of silicon wires. Methods. Study was performed on Wistar rats that were divided into groups: I $(n=10)$ was sham-operated, II $(n=10)$ with $10 \mathrm{~mm}$ sciatic nerve gap bridged with autoneurograft, III $(n=10)$ with nerve gap bridged with freeze-thaw decellularized allogenic aorta filled with $4 \%$ carboxymethylcellulose hydrogel, IV $(n=10)$ with nerve gap bridged with same conduit as III along with longitudinal oriented silicon wires ( $p$-type, Boron-ligated). Parts of the sciatic nerve were harvested for histologic study: 1 week postoperatively the proximal nerve stump, proximal stump-to-graft site and graft site itself were analyzed. 3 weeks after surgery the proximal nerve-to-graft junction and graft site were analyzed. Longitudinal frozen sections were stained with nitric silver via modified Bielschowsky method. The number of nerve fibers was statistically measured and compared.
\end{abstract}

Results. It is stated that 1 week after surgery rats from groups II, III, and IV demonstrated signs of nerve fibers irritation in proximal nerve stump. Proximal nerve-to-graft junction contained thin nerve fibers and moderate amount of cells in group II, but a substantial amount of cells, blood vessels and newly-formed nerve fibers in groups III and IV. Graft site contained degenerated nerve fibers in group II, homogeneous semi-transparent masses in group III and same masses with silicon wires in group IV. 3 weeks after surgery rats from group II demonstrated heterogeneous chaotic distribution of nerve fibers at the proximal nerve-tojunction site and heterogeneous distribution of nerve fibers at the graft site. Group III had proximal neuroma site that was composed of substantial amount of chaotically oriented nerve fibers. Graft site contained thin heterogeneously distributed nerve fibers inside the conduit, which were situated alongside the conduit wall or close to vessels. Group IV had proximal neuroma site that was composed of newly-formed nerve fibers that were situated in certain order and mixed with cells and vessels. At the conduit site, thin nerve fibers grow inside conduit lumen, mixed with vessels, and shift towards the silicon wires.

Conclusions. It can be concluded about the possible tendency of the pro-regenerative effect of silicon wires, used as a component of the nerve graft, as evidenced by more homogeneous and complete graft site neurotization along with the possible appearance of the nerve interface "nerve fiber-silicone microwire".

Keywords: peripheral nerve injury; nerve tissue; peripheral nerve grafting.

\section{Introduction}

During the last decade the incidence of severe peripheral nerves' and plexus injuries such as complete nerve trunk transection or nerve injury remains high in continuity and tends to grow [1]. Such nerve injuries are often observed not only among civilians but also among war casualties [2-5].

According to well-known modern recommendations on reconstructive neurosurgery, nerve reconstruction must be provided without tension [6], so extended nerve lesions must be treated using different bridging strategies [7] Now, Autoneuro- grafting is considered to be a golden standard for nerve damage reconstruction [8], but shortcomings of this method [9] are stipulating the designing of new tools for nerve gap bridging like hollow conduits etc.

As it was shown in recent experimental studies on conduit design, a hollow tube filled with hydrogel and longitudinal oriented structures is considered to be the most perspective tool to promote nerve fibers growth through conduit $[10,11]$.

Another problem that arises from combatrelated injuries of limbs is limb loss due to traumatic amputations [12-14]. 
Such victims of wars must be rehabilitated using the best possible high-tech prosthetic limbs. Last advances in bionics [15] and discovery of the presence of residual action potentials both in motor and sensory nerve fibers at the peripheral nerve stumps of amputees [16] makes the idea of bidirectional mind-controlled prosthetic limbs sound very promising [17].

The integral part of these artificial limbs is the peripheral nerve interface that enables the bi-directional connection between the nerve trunk and an artificial device.

Stability in time, safeness and high fidelity of signals are considered to be the key points of peripheral nerve interface formation $[17,18]$.

Some scientific reviews consider that nerve conduits with filaments inside can be an effective tool both for nerve regeneration and formation of such interfaces [19] but ideal material for them is still needed to be discovered [20].

Keeping in mind that early measures at nerve injury place are crucial for successful nerve regeneration, short-term outcomes of new treatment must be estimated with the histological study [21].

The current study is aimed at investigating the impact of silicon wires on early stages of peripheral nerve structure change after severe injury and grafting.

\section{Materials and Methods}

An experiment was performed on 40 male Wistar rats aged 2-4 month that were placed under the natural light-dark cycle and had free access to water and food.

All manipulations were performed in accordance with "Rules of work using experimental animals", approved by Decree of the Ministry of Health of Ukraine and Directive 2010/63/EU (on the protection of animals used for scientific purposes) of the European Parliament and Council of Europe. The research was approved by Committee on bioethics expertise and scientific research ethics at Bogomolets National Medical University, Minutes № $12,30^{\text {th }}$ of December, 2015.

All surgical interventions were performed under intraperitoneal thiopental anesthesia $(40 \mathrm{mg} / \mathrm{kg})$ [22].

All rats were randomly divided into the next groups:

I $(n=10)$ sham-operated, where the sciatic nerve was exposed, but undamaged.

II $(n=10)$ autologous nerve grafting group, where the right sciatic nerve was exposed in the middle third, $10 \mathrm{~mm}$ of nerve trunk was removed and re-sutured to formed nerve gap with 4 epineural stitches to each stump (10/0 Daflon, B.Braun, Germany) as it was described by Hunt [7]: after nerve ends and graft ends alignment two simple sutures were placed 180 degrees from one another. Two additional sutures were placed on the anterior and posterior sides to approximate the epineurium and prevent fascicular extrusion.

Used model of $10 \mathrm{~mm}$ nerve gap on rat's sciatic nerve was considered as the most common and golden standard model for nerve regeneration study according to the last systematic review [23, 24].

III $(n=10)$ allogenic aorta grafting group, where after sciatic nerve exposure and $10 \mathrm{~mm}$ of nerve trunk excision, the nerve gap was filled with allogenic decellularized aorta mixed with $4 \%$ Carboxymethyl cellulose hydrogel. The conduit was sutured with 2 n-like stitches to each stump (10/0 Daflon, B.Braun, Germany). as it was described by Hunt [7]: two horizontal sutures were placed between conduit and epineurium of the nerve. As sutures were tightened, the nerve was drawn into the conduit.

Decellularization of allogenic aortas was achieved by two cycles of freezing at $-80^{\circ} \mathrm{C}$ for 2 hours and thawing at room temperature for 1 hour $[25,26]$.

IV $(n=10)$ silicon wires grafting group, where after sciatic nerve exposure and $10 \mathrm{~mm}$ of nerve trunk excision the nerve gap was filled with allogenic decellularized aorta filled with $4 \%$ Carboxymethyl cellulose hydrogel and longitudinally oriented silicon wires ( $p$-type, Boron-ligated). The conduit was sutured to nerve stumps in the same way as in group III.

$50-70 \mu \mathrm{m}$ silicon wires were produced via the VLS (Vapor-Liquid-Solid) gold enhanced CVD method (Chemical Vapor Deposition) of silicon via decomposition of silane in gas-flow reactors with hot and cold walls as described by Klymovska. The growth took place at the overall pressure of 10 mbar in the hydrogen and silane (100:1) flowing at the rate of $100 \mathrm{ml} / \mathrm{s}$ [27]

After the production silicon wires had been pre-cleaned with Isopropyl Alcohol for 20 minutes at $85^{\circ} \mathrm{C}$, then treated with diluted $40 \%$ hydrofluoric acid (1:100) for 2 minutes at room temperature and out into deionized water for 15 minutes to remove surface oxide layer [28]. After surface preparation wires were sealed in clean glass vials and sterilized at $180{ }^{\circ} \mathrm{C}$ dry heat for 60 minutes.

1 and 3 weeks after operating the animals from each group were euthanized with thiopental overdose and decapitation.

Parts of the sciatic nerve that were harvested for histologic study: proximal nerve stump, proximal stump-to-conduit junction site and graft site 
dated 1 week after surgery, proximal stump-toconduit junction site and graft site dated 3 weeks after surgery. Timing of performed analysis of proximal stump, proximal regenerative neuroma (nerve-to-graft junction site) and graft site at 1 week after surgery, proximal junction site and graft site at 3 weeks after modeling matches the data about phases of regeneration of nerve gap as it was stated by Belkas [29].

Longitudinal frozen sections were stained with hematoxylin and eosin for a routine examination, were impregnated with nitric silver via modified Bielschowsky method for the visualization of nerve fibers $[30,31]$.

Obtained sections were examined via Olympus BX51 light microscope with Olympus zoom 4040 digital camera (Olympus, Japan).

Keeping in mind that the number and density of nerve fibers are widely used indicators of nerve regeneration, nerve fiber amount was measured at sciatic nerve longitudinal sections [32].

All digital pictures were processed using Image J ver 1.50 software for biomedical images analysis (freeware, $\mathrm{NiH}, \mathrm{USA}$ ).

Obtained statistical data were analyzed via using IBM SPSS Statistics Base v.22 SPSS Statistics Base v.22 software (IBM, USA, Bogomolets National Medical University academic license \#128 dated 01.08.2016).

Distribution of obtained data was analyzed via using D'Augostino\&Pearson test, differences between groups were estimated via Welch's ANOVA tests with post hoc Welch's t-tests [33]. Differences were considered at the significance level $p<0.01$.

\section{Results}

During the 1 and the 3 weeks animals from group I (sham-operated) demonstrated the similar histological structure of sciatic nerve: well-oriented nerve fibers form bundles and pass in a certain order. Few of them got wave-like margins and demonstrated hypoimpregnation.

Macroscopic examination of surgery site revealed that injured sciatic nerves were composed of 5 parts: proximal and distal stumps, graft segment and proximal and distal stump-to-graft junction sites (neuromas).

1 week after operation rats from group II (autologous nerve grafting) had proximal nerve stump that was composed of many irritated nerve fibers with wavy margins and demonstrated hypo- and hyperimpregnation. End of proximal nerve stump contained a lot of nerve fibers with signs of degen- eration: they got wide bulb-like segments, ovoids of degeneration were also present.

Proximal stump-to-graft site contained a few thin newly-formed nerve fibers that were separated with a moderate amount of Schwann cells and fibroblasts. Blood vessels were rarely seen. Graft site contained fragmented nerve fibers and some ovoids of degeneration.

In rats from group III, proximal nerve stump was composed of nerve fibers bundles that were distributed homogeneously and oriented in order. Some of them got wavy margins or demonstrated signs of hypo- and hyperimpregnation.

The proximal nerve-to-conduit junction site in rats from group III (aorta grafting) was composed of a substantial amount of cells and contain thin newly-formed nerve fibers that grew into the lumen of conduit and mixed with a big amount of blood vessels of different diameters. Graft site was filled by homogeneous semi-transparent masses.

Rats from group IV had proximal nerve stump that was composed of wavy hypo- or hyperimpregnated nerve fibers that were ordered and homogeneously distributed.

Proximal neuroma was composed of big amount of cells and contained thin nerve fibers that were growing towards the conduit lumen between a big amount of cells and moderate amount of blood vessels as it was in group III. Graft site also was composed of homogeneous semi-transparent mass and silicone wires (Fig. 1).

3 weeks after operation in group II (autologous nerve grafting) proximal neuroma site contained a moderate amount of thin nerve fibers that were situated relatively chaotically and were intermixed with cells and few small blood vessels.

In turn, the graft site contained thin nerve fibers that were oriented orderly and distributed heterogeneously, passing alongside to residue of degenerated myelin (Fig. 2). Blood vessels were rare, the majority of them were situated near proximal and distal nerve-to-graft sites.

In rats from group III (conduit grafting), proximal neuroma site was composed of substantial amount of nerve fibers with chaotic orientation. The majority of them was deviating from the longitudinal nerve axis.

Graft site contained newly-formed thin nerve fibers that were growing inside the conduit lumen among blood vessels with different size and orientation. Amount of cells was low. New-formed nerve fibers were distributed relatively heterogeneously: the majority of them were placed alongside the conduit wall or close to blood vessels (Fig. 3). 


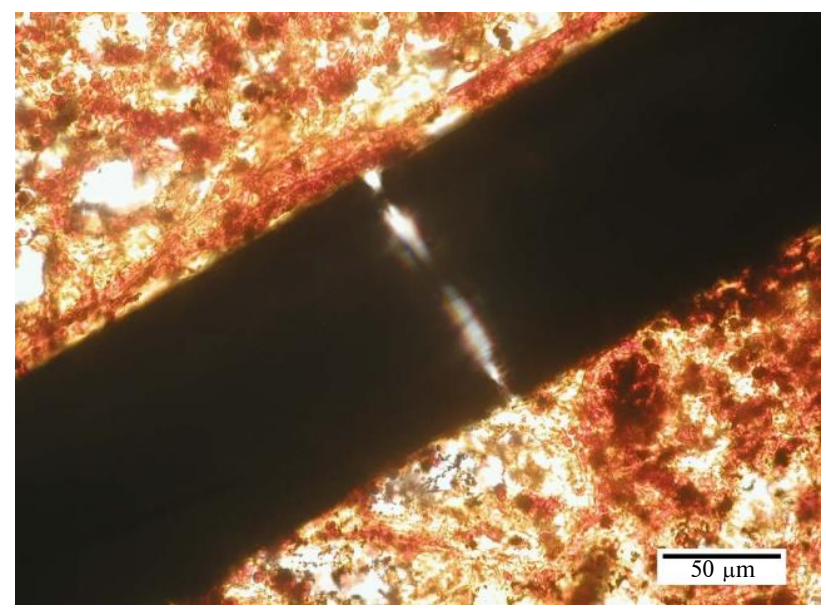

Figure 1: Graft site, from Aorta+gel+silicon wires grafting group (IV), 1 week after surgery. Silicone wire surrounded with semi-transparent mass during matrix phase

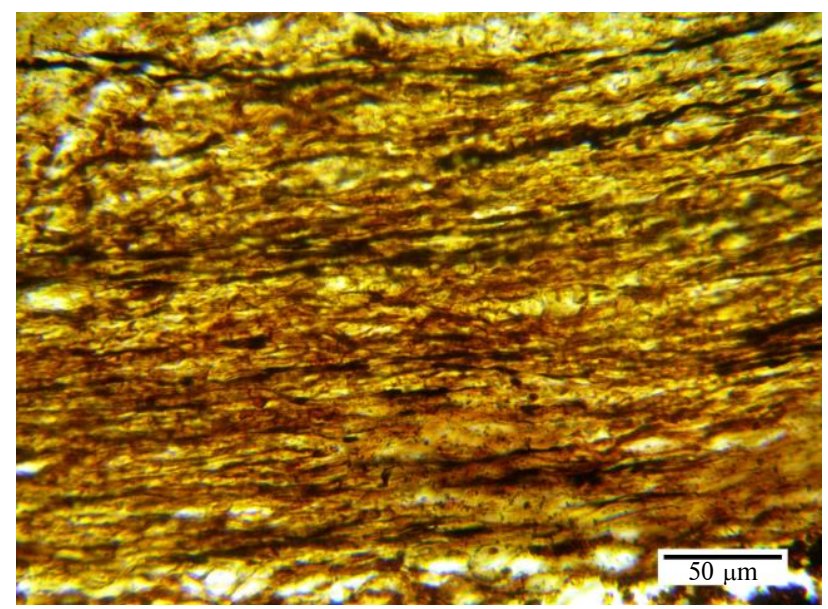

Figure 2: Graft site, from autologous nerve grafting group (II), 3 weeks after surgery. Thin and thick nerve fibers are passing alongside myelin residue

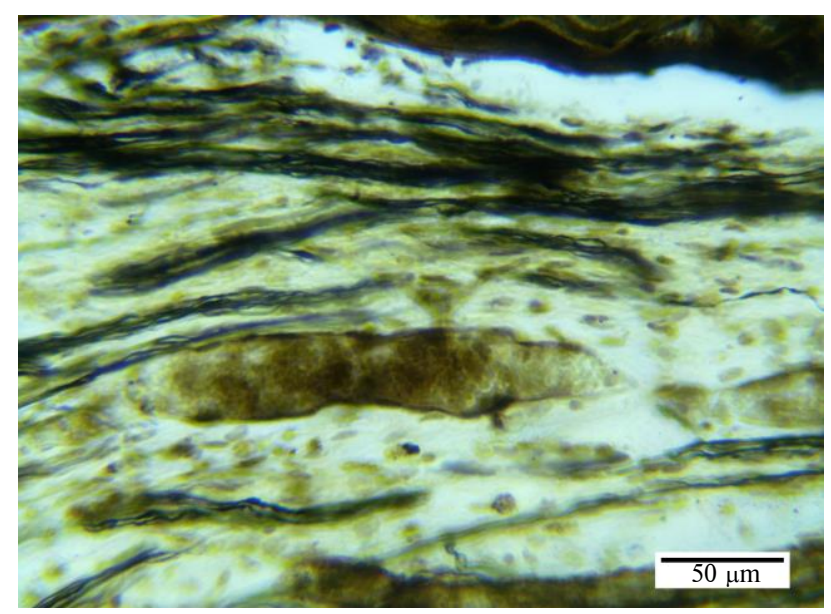

Figure 3: Graft site, from aorta+gel grafting group (III), 3 weeks after surgery. Thin and thick nerve fibers are mixed with blood vessels and rare cells, distributed heterogeneously and are placed alongside the conduit wall
Rats from IV (silicon wires-enhanced grafting) had proximal neuroma site that was composed of a substantial amount of newly-formed nerve fibers that were placed in relative order and mixed with a moderate amount of cells and blood vessels.

Rats from this group also had thin nerve fibers at conduit site that grew inside the lumen of conduit, mixed with blood vessels and deviated towards the silicon wires. Silicone wires were situated exactly at conduit lumen and didn't migrate anywhere. The number of cells was high and some blood vessels that were different in diameter were also present. Distribution of new-formed nerve fibers was relatively homogeneous.

Results of morphometrical analysis and comparison of nerve fibers amount are shown in the Table.

It was revealed that the distribution of nerve fiber density fit Gaussian distribution in each group at all postoperative terms. Wetch's ANOVA test showed the difference between means from each group $(p<0.0001)$ at analyzed sites and terms.

Post hoc t-test at proximal nerve-to-graft site 1 week after surgery showed no difference in nerve fibers density between groups III (conduit without silicon wires) and IV (conduit with silicon wires) $(p=0.630)$ and prominent difference between groups II (autologous nerve grafting) and III (conduit without silicon wires) $(p=0.001)$, together with difference between groups II (autologous nerve grafting) and IV (conduit with silicon wires) $(p=0.001)$

3 weeks after surgery post hoc t-test shown significant difference in nerve fibers density at proximal nerve-to-graft site between III (conduit without silicon wires) and IV (conduit with silicon wires) groups $(p<0.001)$ both with significant difference between groups II (autologous nerve grafting) and III (conduit without silicon wires) $(p<0.001)$. It also was shown the difference in nerve fibers density between groups II (autologous nerve grafting) and IV (conduit with silicon wires) $(p=0.040)$.

3 weeks after surgery post hoc t-test showed the presence of significant difference in nerve fibers density at graft site between groups III (conduit without silicon wires) and IV (conduit with silicon wires) $(p<0.001)$ both with significant difference between groups II (autografting) and III (conduit without silicon wires $)(p<0.001)$. It also was shown the significant difference in nerve fibers density between groups II (autografting) and IV (conduit with silicon wires) $(p=0.041)$. 
Table: Nerve fibers density $\mathrm{mm}^{-1}$ (Mean \pm S.D.) at different sites of injured peripheral nerve

\begin{tabular}{|l|c|c|c|}
\hline \multicolumn{1}{|c|}{ Group name } & $\begin{array}{c}\text { 1 week, } \\
\text { proximal nerve-to-graft site }\end{array}$ & $\begin{array}{c}\text { 3 weeks, } \\
\text { proximal nerve-to-graft site }\end{array}$ & 3 weeks, graft site \\
\hline I - Sham-operated & \multicolumn{3}{|c|}{$10077,33 \pm 211,88$} \\
\hline II - Autografting & $1252.0 \pm 161.0$ & $3939.0 \pm 666.9$ & $3265.0 \pm 440.9$ \\
\hline III - Conduit grafting & $782.3 \pm 193.1^{*}$ & $1265.0 \pm 268.7^{*}$ & $836.7 \pm 150.6^{*}$ \\
\hline $\begin{array}{c}\text { IV - Silicone-enhanced } \\
\text { grafting }\end{array}$ & $823.1 \pm 206.5^{*}$ & $4469.0 \pm 611.9^{*}+$ & $3776.0 \pm 463.9^{*}+$ \\
\hline
\end{tabular}

* - differs from group II; $\$-$ differs from group III.

\section{Discussion}

The presence of fan-like orientation of nerve fibers in proximal stump site and their bulb-like enlargement can be considered as signs of retrograde degeneration and endoneurium swelling in group II (neurografting). Both such findings are showing the beginning of retrograde degeneration along with the presence of irritation signs [32, 34].

Presence of the substantial amount of cells and blood vessels that were growing into the conduit lumen in groups III (aorta+gel) and IV (aorta+gel+Si-wires) indicates to the end of matrix phase both with the early start of the cellular and axonal phases of nerve regeneration at proximal nerve-to-to graft site as it was also described [10, $34,35]$. Presence of only early signs of nerve fibers degeneration at graft site in rats from group II indicates the delay of degeneration due to possible lack of blood supply. Semi-transparent content at graft site on rats from groups III and IV indicates the middle of the matrix phase.

Heterogeneous distribution of newly-formed nerve fibers inside conduit lumen with proximity of their location majorly near conduit inner wall and alongside blood vessels in rats from group III (Aorta+gel grafting) can be attributed to inadequate formation of extracellular matrix during early stages of regeneration with possible lack of mechanical support [10] in contrast with group II (autologous nerve grafting), where endoneurium tubes and Schwann cells were preserved and group IV (Aorta+gel+silicon wires grafting) where intraluminal guides (silicon wires) were present.

Nerve fibers deviation towards the silicon wires in IV (aorta+gel+Si-wires) may indicate the pro-regenerative impact of intraluminal silicone wires not only via simple mechanical support of migrating cells and growing nerve fibers as it was reviewed by Daly [10] but also via neurite outgrow promotion with steady electric field raised from $p$-type silicon wires.
Last findings also are in concordance with classical in vitro and in vivo studies on nerve regeneration and grafting with piezoelectric materials and electrical charged polymers implantation where pro-regenerative properties of such materials were shown [36-38].

As it was shown during histological examination of graft site, the presence of silicon wires at conduit lumen results in a more homogeneous distribution of nerve fibers that can be considered as a better outcome.

High affinity between nerve fibers and semiconductor wires also be explained via possible electrostatic interaction between polarized cell membrane and constant electromagnetic field around boron-ligated silicone wires as it was observed in numerous in vitro experiments on neuron cultivation in presence of steady electric field [39-41] and was described by our research group as possible Coulomb interaction.

Morphometry data showed that rats from group IV demonstrated significantly higher values of nerve fiber diameter amount at neuroma site 3 weeks after surgery, that indicates more homogeneous and full graft site neurotization due to possible silicon wires ability to create the proregenerative microenvironment or assist in mimicking the actual tissue [42].

\section{Conclusions}

The conclusions can be made about the possible pro-regenerative effect of silicon wires that were used as a component of the nerve graft, as evidenced by more homogeneous and more complete graft site neurotization both with a tendency to possible nerve fiber-to-silicone wire interfacing.

\section{Funding}

This study was supported by State Fund for Fundamental Research of Ukraine (grant number F64/25 2015-2016). There is no conflict of interests 
that would imply prejudice to impartiality of the research.

\section{Acknowledgments}

I want to express my gratitude to Yuri Chaikovsky, Alla Klimovska and Alina Korsak for scientific supervision, patience, and useful advice. I also want to thank all technical staff of V.Ye Lashkaryov Institute of Semiconductor physics for silicon wires fabrication and preparing them for implantation.

\section{References}

[1] Patroclo C, Ramalho B, Maia J, Rangel M, Torres F, Souza L, et al. A public database on traumatic brachial plexus injury. 2018. DOI: $10.1101 / 399824$

[2] Castillo-Galvan ML, Martinez-Ruiz FM, de la Garza-Castro. Estudio de la lesion nerviosa periferica en pacientes atendidos por traumatismos. Gaceta Medica de Mexico. 2014;150:527-32.

[3] Missios S, Bekelis K, Spinner R. Traumatic peripheral nerve injuries in children: epidemiology and socioeconomics. J Neurosurg Pediatrics. 2014;14(6):688-94. DOI: 10.3171/2014.8.PEDS14112

[4] Rivera J, Glebus G, Cho M. Disability following combat-sustained nerve injury of the upper limb. The Bone Joint J. 2014;96-B(2):254-58. DOI: 10.1302/0301-620X.96B2.31798

[5] Strafun S, Borzykh N, Haiko O, Borzykh O, Gayovich V, Tsymbaliuk Y. Priority directions of surgical treatment of patients with damage to the peripheral nerves of the upper limb in polystructural injuries. Trauma. 2018;19(3):75-80. DOI: 10.22141/1608-1706.3.19.2018.136410

[6] Bahm J, Esser T, Sellhaus B, El-kazzi W, Schuind F. Tension in peripheral nerve suture. In: Vanaclocha V, Sáiz-Sapena N, editors. Treatment of Brachial Plexus Injuries. IntechOpen; 2019. p. 2-9. DOI: 10.5772/intechopen.78722

[7] Hunt T, Wiesel S. Operative techniques in hand, wrist, and forearm surgery. Philadelphia: Lippincott Williams \& Wilkins; 2011.

[8] Farhadieh R, Bulstrode N, Cugno S. Plastic and reconstructive surgery. Wiley-Blackwell; 2015.

[9] Pi H, Gao Y, Wang Y, Kong D, Qu B, Su X, et al. Nerve autografts and tissue-engineered materials for the repair of peripheral nerve injuries: a 5-year bibliometric analysis. Neural Regen Res. 2015;10(6):1003. DOI: 10.4103/1673-5374.158369

[10] Daly W, Yao L, Zeugolis D, Windebank A, Pandit A. A biomaterials approach to peripheral nerve regeneration: bridging the peripheral nerve gap and enhancing functional recovery. J R Soc Interf. 2011;9(67):202-221. DOI: 10.1098/rsif.2011.0438

[11] Huang J, Patel N, Lyon K. An update-tissue engineered nerve grafts for the repair of peripheral nerve injuries. Neural Regen Res. 2018;13(5):764. DOI: 10.4103/1673-5374.232458

[12] Schoenfeld A, Dunn J, Belmont P. Pelvic, spinal and extremity wounds among combat-specific personnel serving in Iraq and Afghanistan (2003-2011): A new paradigm in military musculoskeletal medicine. Injury. 2013;44(12):1866-70. DOI: $10.1016 /$ j.injury.2013.08.001

[13] Tsema E, Khomenko I, Bespalenko A, Buryanov O, Mishalov V, Kikh A. Clinico-statistical investigation of the extremity amputation level in wounded persons. Klinicheskaia Khirurgiia. 2017;10:51. DOI: 10.26779/2522-1396.2017.10.51

[14] Varma P, Stineman M, Dillingham T. Epidemiology of limb loss. Phys Med Rehabil Clin N Am. 2014;25(1):1-8. DOI: 10.1016/j.pmr.2013.09.001

[15] Seo M, Kim H, Choi Y. Human mimetic forearm mechanism towards bionic arm. In: Proceedings of International Conference on Rehabilitation Robotics; 2017; London. p. 1171-6. DOI: 10.1109/icorr.2017.8009408

[16] Dhillon G, Lawrence S, Hutchinson D, Horch K. Residual function in peripheral nerve stumps of amputees: implications for neural control of artificial limbs. J Hand Surg. 2004;29(4):605-15. DOI: 10.1016/j.jhsa.2004.02.006

[17] Ghafoor U, Kim S, Hong K. Selectivity and longevity of peripheral-nerve and machine interfaces: a review. Front Neurorobot. 2017;11:59. DOI: 10.3389/fnbot.2017.00059

[18] Merrill D, Bikson M, Jefferys J. Electrical stimulation of excitable tissue: design of efficacious and safe protocols. J Neurosci Methods. 2005;141(2):171-98. DOI: 10.1016/j.jneumeth.2004.10.020

[19] Du J, Chen H, Qing L, Yang X, Jia X. Biomimetic neural scaffolds: a crucial step towards optimal peripheral nerve regeneration. Biomater Sci. 2018;6(6):1299-311. DOI: 10.1039/c8bm00260f

[20] Siemionow M. Plastic and reconstructive surgery. London: Springer; 2015.

[21] Chaikovsky YB. Regenerative neuroma. Morphologia. 1999;1(15):55-67.

[22] Flecknell P. Laboratory animal anaesthesia. 4th ed. Academic Press; 2015.

[23] Angius D, Wang H, Spinner R, Gutierrez-Cotto Y, Yaszemski M, Windebank A. A systematic review of animal models used to study nerve regeneration in tissue-engineered scaffolds. Biomaterials. 2012;33(32):8034-9. DOI: 10.1016/j.biomaterials.2012.07.056 
[24] Tos P, Ronchi G, Papalia I, Sallen V, Legagneux J, Geuna S, et al. Chapter 4: methods and protocols in peripheral nerve regeneration experimental research: part I-experimental models. Int Rev Neurobiol. 2009;87:47-79. DOI: $10.1016 / \mathrm{S} 0074-7742(09) 87004-9$

[25] Rodriguez M, Juran C, McClendon M, Eyadiel C, McFetridge P. Development of a mechanically tuneable 3D scaffold for vascular reconstruction. J Biomed Mater Resh Part A. 2012;100A(12):3480-9. DOI: 10.1002/jbm.a.34267

[26] Dang Y, Waxman S, Wang C, Jensen A, Loewen R, Bilonick R, et al. Freeze-thaw decellularization of the trabecular meshwork in an ex vivo eye perfusion model. PeerJ. 2017;5:e3629. DOI: 10.7717/peerj.3629

[27] Klimovskaya A, Kalashnyk Y, Voroshchenko A, Oberemok O, Pedchenko Y, Lytvyn P. Growth of silicon self-assembled nanowires by using gold-enhanced CVD technology. Semiconductor Physics, Quantum Electronics and Optoelectronics. 2018;21(3):282-7. DOI: 10.15407/spqeo21.03.282

[28] Reinhardt K, Kern W. Handbook of silicon wafer cleaning technology. Norwich, NY: William Andrew; 2008.

[29] Belkas J, Shoichet M, Midha R. Peripheral nerve regeneration through guidance tubes. Neurolog Res. 2004;26(2):151-60. DOI: $10.1179 / 016164104225013798$

[30] Kolomiitsev AK, Chaikovsky YB, Tereschenko TL. Fast method of peripheral nervous system nitric silver impregnation suitable for celloidine and parafine slices. Archives of Anatomy, Histology and Embryology. 1981;8:93-6.

[31] Uchihara T. Silver diagnosis in neuropathology: principles, practice and revised interpretation. Acta Neuropathol. 2007;113(5):483-99. DOI: 10.1007/s00401-007-0200-2

[32] Raimondo S, Fornaro M, Di Scipio F, Ronchi G, Giacobini-Robecchi M, Geuna S. Chapter 5: methods and protocols in peripheral nerve regeneration experimental research. Int Rev Neurobiol. 2009;87:81-103. DOI: 10.1016/S0074-7742(09)87005-0

[33] Petrie A, Sabin C. Medical statistics at a glance. Wiley; 2008.

[34] Cajal RS. Degeneration and regeneration of the nervous system. London: Oxford University Press; 1928. DOI: 10.1093/acprof:oso/9780195065169.001.0001

[35] Geuna S, Raimondo S, Ronchi G, Di Scipio F, Tos P, Czaja K, et al. Chapter 3: histology of the peripheral nerve and changes occurring during nerve regeneration. Int Rev Neurobiol. 2009;87:27-46. DOI: 10.1016/S0074-7742(09)87003-7

[36] Aebischer P, Valentini R, Dario P, Domenici C, Galletti P. Piezoelectric guidance channels enhance regeneration in the mouse sciatic nerve after axotomy. Brain Res. 1987;436(1):165-8. DOI: 10.1016/0006-8993(87)91570-8

[37] Fine E, Valentini R, Bellamkonda R, Aebischer P. Improved nerve regeneration through piezoelectric vinylidenefluoridetrifluoroethylene copolymer guidance channels. Biomaterials. 1991;12(8):775-80. DOI: 10.1016/0142-9612(91)90029-a

[38] Valentini R, Vargo T, Gardellajr J, Aebischer P. Electrically charged polymeric substrates enhance nerve fibre outgrowth in vitro. Biomaterials. 1992;13(3):183-90. DOI: 10.1016/0142-9612(92)90069-z

[39] Jaffe L, Poo M. Neurites grow faster towards the cathode than the anode in a steady field. J Exp Zool. 1979;209(1):115-27. DOI: $10.1002 /$ jez.1402090114

[40] McCaig C. Nerve growth in a small applied electric field and the effects of pharmacological agents on rate and orientation. J Cell Sci. 1990;95:617-22.

[41] Patel N, Poo M. Orientation of neurite growth by extracellular electric fields. J Neurosci. 1982;2(4):483-96. DOI: $10.1523 /$ jneurosci.02-04-00483.1982

[42] Dahlin L, Johansson F, Lindwall C, Kanje M. Chapter 28: future perspective in peripheral nerve reconstruction. Int Rev Neurobiol. 2009;87:507-30. DOI: 10.1016/S0074-7742(09)87028-1

\section{В.В. Ліходієвський}

\section{РАННІ ЕКСПЕРИМЕНТАЛЬНІ РЕЗУЛЬТАТИ ЛІКУВАННЯ ТЯЖКИХ ПОШКОДЖЕНЬ ПЕРИФЕРІЙНИХ НЕРВІВ ІЗ ВИКОРИСТАННЯМ НИТКОПОДІБНИХ КРИСТАЛІВ КРЕМНІЮ}

Проблематика. Частота тяжких пошкоджень периферійних нервів і нервових сплетень має тенденцію до зростання. Аутонейропластика продовжує вважатися методом золотого стандарту в лікуванні таких травм, але недоліки цієї методики, такі як додаткове оперативне втручання для отримання фрагментів нерва-донора, денервація інших сегментів тіла, незбіг пучкової структури ушкодженого нерва й аутографту, формують потребу в розробці нових матеріалів і методів лікування.

Мета. Визначення впливу ниткоподібних кристалів кремнію (НКК) на ранні морфологічні зміни травмованого периферійного нерва після тяжкої травми нерва та хірургічного лікування із застосуванням НКК.

Методика реалізації. Дослідження проводилося на статевозрілих щурах-самцях лінії Wistar, що були розділені на такі групи: I $(n=10)$ - псевдооперовані, II $(n=10)$ - із моделюванням 10 мм дефекту сідничого нерва і виконанням аутонейропластики, III $(n=10)$ - із моделюванням десректу нерва, із пластикою алогенною децелюляризованою аортою та 4 \%-ним карбоксиметилцелюлозним гелем, IV $(n=10)$ - із моделюванням 10 мм дефекту сідничого нерва та пластикою алогенною децелюляризованою аортою, 4 \%-ним карбоксиметилцелюлозним гелем і поздовжньо орієнтованими НКК (р-тип, леговані бором). Через 1 та 3 тижні виконували забір матеріалу для гістологічного дослідження: на 1-му тижні аналізували поздовжні зрізи проксимальних відрізків нервів, проксимальних регенераційних невром і ділянку графтів, на 3-му тижні - ділянки проксимальних регенераційних невром і графртів. Оцінювали та порівнювали статистично питому кількість нервових волокон. 
Результати. Встановлено, що на 1-му тижні після операції у щурів II, III та IV груп нервові волокна в ділянці проксимального відрізка нерва демонстрували ознаки подразнення. Ділянка проксимальної регенераційної невроми у щурів II групи містила тонкі нервові волокна і середню кількість клітин; у щурів III та IV груп аналогічна ділянка містила велику кількість клітин, кровоносних судин і тонкі нервові волокна. Ділянка графту містила дегенеруючі нервові волокна у щурів II групи, однорідні напівпрозорі маси у щурів III групи й аналогічні маси із розміщеними в них кристалами кремнію в IV групі. 3 тижні після операції в ділянці регенераційної невроми у щурів II групи були наявні хаотично розміщені та нерівномірно розподілені нервові волокна. На цьому терміні дослідження в аналогічній ділянці нерва у щурів III групи були наявні хаотично орієнтовані нервові волокна, що вростали в просвіт графту, розміщуючись там нерівномірно, переважно вздовж стінки або кровоносних судин. У щурів IV групи на цьому терміні дослідження проксимальна неврома містила впорядковані нервові волокна, що розміщувалися серед великої кількості клітин і кровоносних судин. Ділянка кондуїту містила тонкі новоутворені нервові волокна, що перемежовані клітинами та численними кровоносними судинами і відхиляються в бік НКК.

Висновки. Можна говорити про ймовірну тенденцію до покращення результатів регенерації травмованого периферійного нерва внаслідок впливу НКК, які використовувалися як компонент імплантата, що підтверджується більш рівномірною та повною невротизацією ділянки графту одночасно із вірогідним формуванням інтерфейсу “нервове волокно-ниткоподібний кристал”.

Ключові слова: травма периферійного нерва; нервова тканина; протезування нервів.

\section{В.В. Лиходиевский}

\section{РАННИЕ ЭКСПЕРИМЕНТАЛЬНЫЕ РЕЗУЛЬТАТЫ ЛЕЧЕНИЯ ТЯЖЕЛЫХ ПОВРЕЖДЕНИЙ ПЕРИФЕРИЧЕСКИХ НЕРВОВ С ИСПОЛЬЗОВАНИЕМ НИТЕВИДНЫХ КРИСТАЛЛОВ КРЕМНИЯ}

Проблематика. Частота тяжелых повреждений периферических нервов и их сплетений имеет тенденцию к росту. Аутонейропластика продолжает оставаться методом золотого стандарта в лечении таких травм, однако недостатки данной методики, такие как необходимость выполнения дополнительной операции для получения фрагментов нерва-донора, денервация других сегментов тела, несовпадение пучковой структуры поврежденного нерва и аутографрта, создают потребность в разработке новых материалов и методов лечения.

Цель. Определение влияния нитевидных кристаллов кремния (НКК) на ранние морфологические изменения травмированного периферического нерва после тяжелой травмы и хирургического лечения с применением НКК.

Методика реализации. Исследование проводилось на половозрелых крысах-самцах линии Wistar, которые были разделены на такие группы: I ( $n=10)$ - псевдооперированные, II $(n=10)$ - животные с моделированием 10 мм дефекта седалищного нерва и выполнением аутонейропластики, III $(n=10)$ - животные с моделированием 10 мм дефекта седалищного нерва, который был замещен аллогенной децеллюляризированной аортой, наполненной 4 \%-ным карбоксиметилцеллюлозным гидрогелем, IV $(n=10)$ - животные с моделированием 10 мм дефекта седалищного нерва, который был замещен аллогенной децеллюляризированной аортой, наполненной 4 \%-ным карбоксиметилцеллюлозным гидрогелем и продольно ориентированными НКК ( $p$-тип, легирование бором). Через 1 и 3 недели проводили забор материала для гистологического исследования: на 1-й неделе анализировали проксимальные отрезки нервных стволов, проксимальных регенерационных невром, на 3-й неделе - фрагменты проксимальных регенерационных невром, фрагменты участка графта. Оценивали и статистически сравнивали удельное количество нервных волокон.

Результаты. Установлено, что на 1-й неделе после операции у крыс II, III та IV групп нервные волокна в участке проксимального отрезка нерва демонстрировали признаки раздражения. Участок проксимальной регенерационной невромы у крыс II группы содержал тонкие нервные волокна и среднее количество клеток, у крыс III, IV групп аналогичный участок содержал большое количество клеток, кровеносных сосудов и тонкие нервные волокна. 3 недели после операции на участке проксимальной регенерационной невромы у крыс II группы наблюдались хаотично расположенные и неравномерно распределенные нервные волокна. На этом сроке исследования на аналогичном участке нерва у крыс III группы наблюдались хаотично расположенные нервные волокна, врастающие в просвет графта, расположенные там неравномерно, преимущественно вдоль внутренней стенки или вдоль сосудов. У крыс IV группы на этом сроке исследования проксимальная неврома содержала упорядоченные нервные волокна, расположенные среди большого количества кровеносных сосудов и клеток. Участок графта содержал тонкие новообразованные нервные волокна, перемежеванные клетками и сосудами и отклоняющиеся в сторону НКК.

Выводы. Можно говорить о вероятной тенденции к улучшению результатов регенерации травмированного периферического нерва вследствие воздействия НКК, которые использовались в качестве компонента имплантата, что подтверждается более равномерной и полной невротизацией участка графтта одновременно с вероятным формированием интерфейса "нервное волокно-нитевидный кристалл".

Ключевые слова: травма периферического нерва; нервная ткань; протезирование нервов. 